\section{Transsphenoidal encephalocele, colpocephaly and corpus callosum agenesis in a midline cleft lip and palate patient: A very rare case}

Sir,

A very few case reports were done in the literature about transsphenoidal encephalocele (TSE) with colpocephaly and corpus callosum agenesis in a midline cleft lip and palate patient. No such case report was made from India.

Basal encephalocele (BE) occurs due to herniation of neural elements including pituitary gland or optic apparatus, through a defect in the skull base. TSE represents $<5 \%$ of all BEs with an estimated incidence of 1 in 700,000 live births. ${ }^{[1]}$

Clinical presentation is most often insidious except in those cases where a large herniation protrudes through the epipharynx. They are often associated with hypertelorism, broad nasal root, cleft lip/palate, optic nerve anomalies and agenesis of the corpus callosum. ${ }^{[2]}$

In this case, a 10-year-old boy presented with speech problem and mild difficulty in breathing due to midline cleft lip and palate defect - Tessier cleft 0 . At birth, his growth parameters were appropriate for age. On facial examination, broad nasal alar base and midline cleft lip repair scar mark were present. Systemic examination was unremarkable. The cleft lip was operated at 6 months of age, and no intraoral mass was seen that time.

This time intraoperatively, we found a pulsatile, normal mucosal colour, compressible mass protruding from nasal cavity and clearly visible through the cleft palate [Figure 1].

To know the reason of that mass, magnetic resonance imaging (MRI) of the brain was carried out. MRI report showed features suggestive of corpus callosum agenesis, TSE, colpocephaly, absence of septum pellucidum and dilated and high-riding third ventricle [Figure 2].

Neurosurgical opinion was sought and asked the patient to review with endocrinologist in view of the high risk of hypothalamopituitary dysfunction.

To correct the speech problem and to protect the TSE, secondary incomplete midline cleft palate was repaired by pushback technique left untouched TSE. This encephalocele was planned for operation in his second decade of life through transnasal approach.

Post-operative follow-up period patient was relieved from breathlessness and improvement of speech as compared to earlier. Patient and his guardians are happy with the outcome.

Inconclusion, thepresence ofmidlinecraniofacialanomalies in association with symptoms of nasal obstruction, persistent rhinorrhoea, visual deficits and endocrine dysfunction should alert the surgeons/physicians to the possible presence of BE. Plastic surgeons may encounter this surprise finding during cleft palate repair and should be aware of the plan of action in case of such discovery.

Guardians of the patient should keep him away from contact sports and be aware of avoid nasal suctioning.

Indications for surgical intervention include significant airway obstruction, repeated meningitis, recurrent rhinorrhoea, progressive loss of vision due to TSE or $\mathrm{BE}$. Endoscopic route is preferred because of the high 




Figure 1: Intraoral examination reveals secondary cleft palate and the pulsatile mass

rate of post-operative hypothalamopituitary dysfunction following transcranial approach. ${ }^{[3]}$ If neurosurgeons want to intervene at the same time of cleft palate repair, through wide gap of cleft palate approach would be a better option or cleft palate repair may be postponed till TSE repair.

Treatment options ${ }^{[4]}$ include

1. Early management of elevated intracranial pressure

2. To prevent sac rupture, urgent closure of skin defects and/or removal of non-functional extracerebral tissue with watertight dural closure

3. Bone correction-frontal remodelling, nasal bone grafting with attention to prevention of "long-nose" deformity

4. Correction of telecanthus with the transnasal wiring. Correction of dystopia and hypertelorism can be performed in the same stage.

\section{Declaration of patient consent}

These authors certify that they have obtained all appropriate patient consent forms. In the form, the legal guardian has given his consent for images and other clinical information to be reported in the journal. The Guardian understands that names and initials will not be published and due efforts will be made to conceal patient identity, but anonymity cannot be guaranteed.

\section{Financial support and sponsorship}

Nil.

\section{Conflicts of interest}

There are no conflicts of interest.

\section{Indranil Dutta, Guruaribam Nilamani Sharma, Khungdombam Palin Singh}

Department of Plastic Surgery, Shija Hospitals and Research Institute, Imphal West, Manipur, India

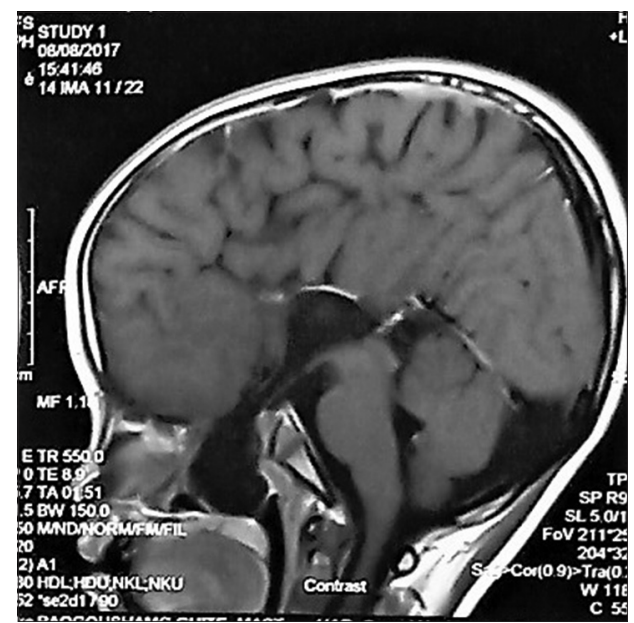

Figure 2: Transsphenoidal herniation of meninges with cerebrospinal fluid and part of basifrontal cortex suggestive of transsphenoidal encephalocele

Address for correspondence: Dr. Indranil Dutta

Quarter No. 11, Doctor's Quarter, Shija Hospitals and Research Institute, Langol, Imphal West - 795 004, Manipur, India.

E-mail: drindranil035@gmail.com

\section{REFERENCES}

1. Sanjari R, Mortazavi SA, Amiri RS, Ardestani SH, Amirjamshidi A. Intrasphenoidal meningo-encephalocele: Report of two rare cases and review of literature. Surg Neurol Int 2013;4:5.

2. Chandran S, Raturi S, Pillay HM, James TE. Transsphenoidal encephalocele masquerading as nasal mass in a 2-year-old boy. BMJ Case Rep 2014;2014. pii: bcr2013201426.

3. Monteiro $M$, de Albuquerque AC, Nobre MC, Veloso AT, Mendes VA, de Souza Filho LD, et al. Transspheinoidal transpalatal meningoencephalocele. Arq Neuropsiquiatr 2006;64:624-7.

4. Tsutsumi K, Asano T, Shigeno T, Matsui T, Ito S, Kaizu H, et al. Transcranial approach for transsphenoidal encephalocele: Report of two cases. Surg Neurol 1999;51:252-7.

This is an open access journal, and articles are distributed under the terms of the Creative Commons Attribution-NonCommercial-ShareAlike 4.0 License, which allows others to remix, tweak, and build upon the work non-commercially, as long as appropriate credit is given and the new creations are licensed under the identical terms.

\begin{tabular}{|l|l|}
\hline \multicolumn{2}{|c|}{ Access this article online } \\
\hline Quick Response Code: & Website: \\
\hline
\end{tabular}

How to cite this article: Dutta I, Sharma GN, Singh KP. Transsphenoidal encephalocele, colpocephaly and corpus callosum agenesis in a midline cleft lip and palate patient: A very rare case. Indian J Plast Surg 2018;51:334-5.

() 2019 Indian Journal of Plastic Surgery | Published by Wolters Kluwer - Medknow 